UDC 577.218; 616.006.6

\title{
Heterozygous deletions are main cause of expression alterations of PPM1M and PRICLE2 genes in human clear cell renal cell carcinomas
}

\author{
E. E. Rudenko', Y. V. Lapska ${ }^{1}$, G. V. Gerashchenko ${ }^{1}$, \\ E. O. Stakhovsky², M. V. Vikarchuk², V. I. Kashuba ${ }^{1}$ \\ ${ }^{1}$ State Key Laboratory of Molecular and Cellular Biology \\ Institute of Molecular Biology and Genetics, NAS of Ukraine, \\ 150, Zabolotnoho Str., Kyiv, Ukraine, 03680 \\ ${ }^{2}$ National Cancer Institute, \\ 33/43, Lomonosova Str., Kyiv, Ukraine, 03022 \\ rudenko_jene@ukr.net
}

\begin{abstract}
Aim. To discover the mechanisms of the PPM1M and PRICKLE2 genes expression alterations in clear cell renal cell carcinomas. Methods. Study of the copy number was performed, using the quantitative PCR (Q-PCR). Results. Deletions of PPM1M were found in $55 \%$ of cases, amplifications - in $17 \%$ and in $28 \%$ of samples there were no changes of the copy number. We found the deletions of PRICKLE2 in $50 \%$ of samples, no changes of the copy number in $39 \%$, and amplifications in $11 \%$ of cases. Conclusions. By the analysis of the gene copy number we have shown that homo- and heterozygous deletions are the main reason of changes in expression of the PPM1M and PRICKLE2 genes.
\end{abstract}

Keywords: clear cell renal cell carcinoma, heterozygous deletions, quantitative PCR, copy number analysis.

\section{Introduction}

Annual incidence of tumors of the genitourinary system is over 200 thousand worldwide. During 2011 the kidney cancer was diagnosed in 5622 patients in Ukraine; 2469 of them died. For a quarter of these patients a period from the time of diagnosis to death is very short, less than one year (see http://www.ncru.inf. ua/publications/BULL_14/PDF_E/49-50-poch.pdf). Among urologic tumors, clear cell renal cell carcinoma (ccRCC later on in the text) takes the third place in incidence, following prostate and bladder cancer. ccRCC is the first by the number of death. ccRCC is the prevalent malignancy of the kidney, accounting for about 85 $\%$ of kidney cancers [1]. Kidney carcinoma is associated with the most negative prognosis and responds poorly to medical treatment, as a rule [2]. The course of disease and treatment depends on the molecular profile of tumors. Very important is to study the expression pattern of tumor suppressor genes (TSG) that play an important role in cancerogenesis. The TSG expression is usually downregulated in tumors by different mechanisms, such as genetic and epigenetic alterations. One of the most frequent aberrations in solid tumors is inactivation of TSG in chromosome 3 [3]. Using the NotImicroarray to study ccRCC samples, we have found that the PPM1M and PRICLE2 genes showed genetic and/or epigenetic changes [4]. It has been already shown that these genes play the role of TSG in cervical, ovarian and lung cancers [5-7].

Earlier we have shown that a reduction in the PPM1M and PRICKLE2 expression is typical for ccRCC; no promoter methylation was found for these genes, however [8]. It is known that these proteins are

C 2015 E. E. Rudenko et al.; Published by the Institute of Molecular Biology and Genetics, NAS of Ukraine on behalf of Biopolymers and Cell. This is an Open Access article distributed under the terms of the Creative Commons Attribution License (http://creativecommons.org/licenses/by/4.0/), which permits unrestricted reuse, distribution, and reproduction in any medium, provided the original work is properly cited 
involved in the signalling pathways associated with carcinogenesis. In particular, PPM1M inhibits the IL1-NF-kappaB signalling pathway by selective dephosphorylating of IKKbeta [9]. PRICKLE2 is involved in the WNT pathway of planar cell polarity determination (PCP), which regulated the polarity and movement of cells [10]. Therefore, there is a possibility that these two genes might be TSGs in ccRCC.

In the present work we performed a detailed study of heterozygous deletions of the PPM1M and PRICKLE2 genes in ccRCC and propose the new mechanism of deletion of these genes during carcinogenesis.

\section{Materials and Methods}

Tissue samples. Samples of surgically removed tumors and surrounding tissues (considered as normal) were obtained from Kyiv National urology center (Kyiv, Ukraine). All tissue samples were characterized according to the International System of Clinical and morphological classification of tumors (TNM) [11] and WHO classification criteria [12]. The average age of patients was 48.59 (in the range of 30-68 years). Normal tissues were obtained at a distance of at least $2 \mathrm{~cm}$ from the tumor and histologically confirmed as unchanged renal epithelial cells. Altogether, 18 samples of ccRCC were investigated, i.e. 12 samples at stage 1-2 and 6 samples at stage 3-4.

\section{Isolation of genomic DNA}

Genomic DNA was isolated, using DNA purification Kit (Fermentas, Lithuania), according to the manufacturer's re-commendations. Quality of genomic DNA was as-

Table 1. Summary of analysis on gene copy number in ccRCC samples

\begin{tabular}{|c|c|c|c|c|c|c|}
\hline $\begin{array}{l}\text { Sample } \\
\text { number }\end{array}$ & Sex & $\begin{array}{c}\text { Stage } \\
\text { of atypia }\end{array}$ & Age & $\begin{array}{c}\text { TNM } \\
\text { classification }\end{array}$ & $\begin{array}{l}\text { Copy number } \\
\text { of } P P M 1 M\end{array}$ & $\begin{array}{l}\text { Copy number } \\
\text { of PRICKLE2 }\end{array}$ \\
\hline 1 & M & 1 & 38 & $\mathrm{~T} 2 \mathrm{NxM} 0$ & $0.979[0.979 ; 0.981]$ & $0.409[0.408 ; 0.409]$ \\
\hline 2 & $\mathrm{M}$ & 1 & 47 & T2NxM0 & $2.761[2.720 ; 2.801]$ & $0.979[0.979 ; 0.980]$ \\
\hline 3 & $\mathrm{~F}$ & 1 & 43 & T3N0M0 & $0.677[0.614 ; 0.740]$ & $1.287[1.149 ; 1.426]$ \\
\hline 4 & M & 1 & 38 & $\mathrm{~T} 2 \mathrm{NxM} 0$ & $1.212[1.045 ; 1.377]$ & $0.848[0.781 ; 0.914]$ \\
\hline 5 & $\mathrm{~F}$ & 2 & 46 & T2NxM0 & $0.759[0.707 ; 0.811]$ & $0.809[0.790 ; 0.829]$ \\
\hline 6 & $\mathrm{~F}$ & 2 & 46 & $\mathrm{~T} 2 \mathrm{NxM} 0$ & $0.933[0.897 ; 0.970]$ & $1.009[0.911 ; 1.108]$ \\
\hline 7 & M & 2 & 41 & T3NxM0 & $0.706[0.439 ; 0.973]$ & $0.808[0.729 ; 0.888]$ \\
\hline 8 & M & 2 & 50 & T2NxM0 & $0.973[0.935 ; 1.011]$ & $1.631[1.575 ; 1.686]$ \\
\hline 9 & $\mathrm{~F}$ & 2 & 45 & $\mathrm{~T} 2 \mathrm{NxM} 0$ & $2.418[1.947 ; 2.889]$ & $0,579[0,528 ; 0,631]$ \\
\hline 10 & $\mathrm{~F}$ & 2 & 66 & T3N0M0 & 0.507 [0.406: 0.608$]$ & $0.933[0.879 ; 0.989]$ \\
\hline 11 & M & 2 & 68 & T2NxM0 & $0.631[0.591 ; 0.671]$ & $0.470[0.465 ; 0.474]$ \\
\hline 12 & M & 2 & 38 & T2NxM0 & $0.366[0.318 ; 0.415]$ & $0.431[0.363 ; 0.501]$ \\
\hline 13 & M & 3 & 45 & T2NxM0 & $0.847[0.814 ; 0.880]$ & $1.044[0.850 ; 1.238]$ \\
\hline 14 & $\mathrm{M}$ & 3 & 67 & $\mathrm{~T} 2 \mathrm{NxM} 0$ & $0.398[0.374 ; 0.375]$ & $1.025[0.970 ; 1.080]$ \\
\hline 15 & M & 3 & 46 & T2N0M0 & $0.705[0.701 ; 0.708]$ & $1.146[0.989 ; 1.303]$ \\
\hline 16 & $\mathrm{~F}$ & 4 & 61 & T3N0M0 & $0.884[0.690 ; 1.077]$ & $1.429[1.261 ; 1.597]$ \\
\hline 17 & $\mathrm{M}$ & 4 & 51 & T3N0M0 & $1.675[1.405 ; 1.945]$ & $0.525[0.509 ; 0.541]$ \\
\hline 18 & M & 4 & 62 & $\mathrm{~T} 2 \mathrm{NxM} 0$ & $0.223[0.213 ; 0.233]$ & $0.368[0.314 ; 0.422]$ \\
\hline
\end{tabular}

Note: Samples, which displayed ratio $<0.35$ and where gene was considered as homozygously deleted are marked bold italic. Samples, which displayed ratio $<0.85$ and $\geq 0.35$ and where genes were considered as heterozygously deleted are shown in italic. Samples, which had ratio $>0.85$ and where genes showed unchanged copy number are marked regular text Samples, which displayed ratio $>1.5$ and where genes were amplified marked bold. 
sessed by agarose gel electrophoresis; DNA concentration was measured, using a spectrophotometer NanoDrop ND-1000 (NanoDrop Technologies Inc., USA). The samples used for the Q-PCR reactions were of high molecular weight (OD 260/280 was in range 1.6-1.8).

Analysis of gene copy number. The Q-PCR method and Bio-Rad iQ5 machine to quantify the number of gene copies were used. It was shown that this method is accurate enough to determine the number of allele copies. Each Q- PCR reaction contained $12.5 \mathrm{ul}$ 2xSYBR Green PCR Master Mix (Fermentas, Lithuania), forward and reverse primers at a concentration of $400 \mathrm{nM}$, genomic DNA - $10 \mathrm{ng} / \mathrm{ml}$, and sterile water to make a final volume $25 \mathrm{ul}$. Gene TBP was used as the reference [13]. The primer design was carried out, using a program Primer3 (http://frodo.wi.mit.edu/ primer3/) and Integrated DNA Technologies, http:// eu.idtdna.com/ analyzer/Applications/Oli goAnalyzer/). The following primers were used (Invitrogen):

\section{PPM1M_copy}

LEFT PRIMER 5'-TCCGAATCCTGACAACTTC-3' RIGHT PRIMER 5'- CCGAATGCTGGAACT CTA-3'

\section{PRICKLE2_copy}

LEFT PRIMER 5'-ATGTTTGCTCCTGGTTT CA-3' RIGHT PRIMER 5'-ACTCAGACCCTCAGTTCAC-3'

\section{TBP_copy}

LEFT PRIMER 5'-ATAAAGCAGCAGCAGG GTTT-3' RIGHT PRIMER 5'-AGTCAGTGTGGCAAACTTCG-3'

PCR was performed at the following conditions: denaturation at $95^{\circ} \mathrm{C}$ for $10 \mathrm{~min}$, after this 35 cycles: denaturation at $95{ }^{\circ} \mathrm{C}$ for $20 \mathrm{sec}$, annealing at $60{ }^{\circ} \mathrm{C}$ for $20 \mathrm{sec}$, and elongation at $72{ }^{\circ} \mathrm{C}$ for $40 \mathrm{sec}$.

Analysis of the number of copies of the PPM1M and PRICKLE2 genes was performed by $2-\Delta \triangle \mathrm{CP}$ relative quantitative analysis [14].

According to the histological analysis, the contamination of tumour samples by normal stroma lymphocytes could be up to 30-40\%. Therefore, the homozygous deletions were considered when the calculated values were below 0.35 ; the heterozygous deletions were proposed if the calculated values were below 0.85 . The locus was considered as amplified if the smallest of the range exceeded 1.5 [15].

\section{Results and Discussion}

An analysis of the gene copy number was performed for 18 samples of ccRCC and corresponding to them normal tissues (Table 1).

The PPM1M gene was deleted in $55.6 \%$ of cases (nine cases of heterozygous deletions and one homozygous deletion). Amplification were observed in $16.7 \%$ (three samples), while $27.8 \%$ cases were unchanged (five samples). Previously we have reported that the expression level of PPM1M altered in $50 \%$ of cases in ccRCC tumors [8].

The product of PPM1M gene is a serine threonine phosphatase from the PPM family $\left(\mathrm{Mg}^{2+}\right.$ - and $\mathrm{Mn}^{2+}$ dependent). Phosphorylation is an important post-translation modification that regulates many signaling systems and it is an effective way to control cellular internal and external signal responses [16]. Phosphatases together with kinases regulate phosphorylation and are involved in many physiological processes, such as cell migration, proliferation, intracellular substrate localization, apoptosis, differentiation, metabolism, and immune system response [17].

Phosphatases are also involved in the cell cycle regulation [18], therefore they are considered as suppressors of tumor growth. Most probably, they should be inactivated in the process of carcinogenesis. One of the functions of PPM1M is the inhibition of the IL-1-induced activation of NF-kappa-B. The IL-1 is a cytokine that has different functions in control of inflammation. [9].It is yet un known how PPM1M is involved in cancerogenesis [19].

Deletions in the PRICKLE gene were found in $50 \%$ of samples (eight samples heterozygous deletions and one homozygous deletion). In $38.9 \%$ (seven samples) there were no changes in the copy number, while amplification was observed in $11.1 \%$ of cases (two samples). According to our previous data, the expression level of PRICKLE2 altered in $83 \%$ of cases [8].

The PRICKLE2 protein is a member of WNT-cascade that activates Fz-receptors on the cell surface. This pathway regulates the planar polarization of the cells that differ from the basal-apical polarization and is, actually, perpendicular to the latter [20]. Apart that the PRICKLE2 is attached to the inner surface 
of the cell membrane by another protein - PCP-strabismus, not much is known about its function [21].

\section{Conclusions}

Previously, we have shown that the expression of PRICKLE2 and PPM1M altered in ccRCC. In the present paper by the analysis of the gene copy number we have shown that homo- and heterozygous deletions are the main reason of changes in the expression of these genes.

\section{Funding}

This work was partially supported by the project «Identification of molecular genetic markers for diagnostics of malignant neoplasms of epithelial origin», state registration N $0110 \mathrm{U} 004744$.

\section{REFERENCES}

1. Cheville JC, Lohse CM, Zincke H, Weaver AL, Blute ML. Comparisons of outcome and prognostic features among histologic subtypes of renal cell carcinoma. Am J Surg Pathol. 2003;27(5):612-24.

2. Bhat $S$. Role of surgery in advanced/metastatic renal cell carcinoma. Indian J Urol. 2010;26(2):167-76.

3. Pavlovich CP, Schmidt LS, Phillips JL. The genetic basis of renal cell carcinoma. Urol Clin North Am. 2003;30(3):43754.

4. Dmitriev AA, Rudenko EE, Kudryavtseva AV, et al. Epigenetic alterations of chromosome 3 revealed by NotI-microarrays in clear cell renal cell carcinoma. BioMed Research International. 2014;2014:1-9.

5. Senchenko VN, Kisseljova NP, Ivanova TA, et al. Novel tumor suppressor candidates on chromosome 3 revealed by NotI-microarrays in cervical cancer. Epigenetics. 2013;8 (4):409-20.

6. Dmitriev AA, Kashuba VI, Haraldson K, et al. Genetic and epigenetic analysis of non-small cell lung cancer with NotImicroarrays. Epigenetics. 2012;7(5):502-13.

7. Kashuba V, Dmitriev AA, Krasnov GS, et al. NotI microarrays: novel epigenetic markers for early detection and prognosis of high grade serous ovarian cancer. Int J Mol Sci. 2012;13(10):13352-77.
8. Rudenko EE, Gerashchenko GV, Lapska YV, Vozianov SO, Zgonnyk YM, Kashuba VI. PPM1M and PRICKLE2 are potential tumor suppressor genes in human clear-cell renal cell carcinoma. Biopolym Cell. 2014; 30(3):229-233.

9. Henmi T, Amano K, Nagaura Y, et al. A mechanism for the suppression of interleukin-1-induced nuclear factor kappaB activation by protein phosphatase 2Ceta-2. Biochem J. 2009; 423(1):71-8.

10. Katoh $M$. WNT/PCP signaling pathway and human cancer (review). Oncol Rep. 2005;14(6):1583-8.

11. Speissel B, Beahrs OH, Hermanek P, Hutter RVP, Scheibe O. TNM atlas: illustrated guide to the TNM. pTNM classification of malignant tumours. Berlin New York: Springer-Verlag. 1989.

12. Travis WD, Coby TV, Corrin B, Shimosato Y, Brambilla E. World Health Organization International Histological Classification of Tumours; Histological typing of lung and pleural tumours. Berlin: Springer. 1999.

13. Jung M, Ramankulov A, Roigas J, et al. In search of suitable reference genes for gene expression studies of human renal cell carcinoma by real-time PCR. BMC Mol Biol. 2007; 8:47.

14. Gerashchenko GV, Bogatyrova OO, Rudenko EE, et al. Genetic and epigenetic changes of NKIRAS1 gene in human renal cell carcinomas. Exp Oncol. 2010;32(2):71-5.

15. Senchenko VN, Liu J, Loginov W, et al. Discovery of frequent homozygous deletions in chromosome 3p21.3 LUCA and AP2 0 regions in renal, lung and breast carcinomas. Oncogene. 2004;23(34):5719-28.

16. * Shakir SM, Bryant KM, Larabee JL. Regulatory interactions of a virulence-associated serine. threonine phosphatase-kinase pair in Bacillus anthracis. J Bacteriol. 2010; 192(2):400-9.

17. Shi $Y$. Serine/threonine phosphatases: mechanism through structure. Cell. 2009;139(3):468-84.

18. Dedinszki $D$, Kiss A, Márkász L, et al. Inhibition of protein phosphatase-1 and -2A decreases the chemosensitivity of leukemic cells to chemotherapeutic drugs. Cell Signal. 2015; 27(2):363-72.

19. Komaki K, Katsura K, Ohnishi M, et al. Molecular cloning of PP2Ceta, a novel member of the protein phosphatase $2 \mathrm{C}$ family. Biochim Biophys Acta. 2003;1630(2-3):130-7.

20. Fanto $M$, McNeill $H$. Planar polarity from flies to vertebrates. J Cell Sci. 2004;117(Pt 4):527-33.

21. Bastock R. Strabismus is asymmetrically localised and binds to Prickle and Dishevelled during Drosophila planar polarity patterning. Development. 2003;130(13):3007-14. 
Є. Є. Руденко, Ю. В. Лапська, Г. В. Геращенко, Е. О. Стаховський, М. В. Вікарчук, В. І. Кашуба

Гетерозиготні делеції - основна причина змін експресії генів PPM1M та PRICKLE2 у світлоклітинних карциномах нирки людини

Мета. Знайти механізм, відповідальний за зміну експресії генів PPM1M і PRICKLE2 у світлоклітинних карциномах нирки людини. Методи. Вивчення змін кількості копій генів було проведено за допомогою кількісної ПЛР (Q- ПЛР). Результати. Делеції гена РPM1M були знайдені у 55,6 \% випадків, ампліфікації - у 16,7 \%, а у 27,8 \% зразків не було змін кількості копій гена. Ми виявили делеції гена PRICKLE2 у 50 \% зразків, зміни не виявлено у 38,9 \% зразків, а ампліфікації спостерігалися у 11,1 \% випадків. Висновки. За допомогою аналізу кількості копій гена ми показали, що гомо- та гетерозиготні делеції є головною причиною зміни експресії генів PPM1M i PRICKLE2.

Кл юч о в і сл о в а: світлоклітинна карцинома нирки, гетерозиготні делеції, кількісна ПЛР, аналіз кількості копій гена.
Е. Е. Руденко, Ю. В. Лапская, А. В. Геращенко, Э. А. Стаховский, М. В. Викарчук, В. И. Кашуба.

Гетерозиготные делеции являются основной причиной изменения экспресии генов PPM1M и PRICKLE2 в светлоклеточных карциномах почки человека

Цель. Найти механизм, ответственный за изменение экспрессии генов PPM1M и PRICKLE2 в светлоклеточных карциномах почки человека. Методы. Изучение изменений количества копий проводили методом количественной ПЦР (Q-ПЦР). Результаты. Делеции гена РPM1M были найдены в 55,6 \% случаев, амплификации - в 16,7 \%, а в 27,8 \% образцов не было изменений количества копий гена. Мы обнаружили делеции гена PRICKLE2 в 50 \% образцов, в 38,9 \% образцов изменений не обнаружено, амплификации наблюдались в 11,1 \% случаев. Выводы. С помощью анализа количества копий гена мы показали, что гомо- и гетерозиготные делеции являются главной причиной изменения экспресии генов PPM1M и PRICKLE2.

Ключевые слова: светлоклеточная карцинома почки, гетерозиготные делеции, количественный ПЦР, анализ количества копий гена.

Received 30.12.2014 